Egypt. Acad. J. biolog. Sci., Vol.4 (1) 113-124 (2012) C. Physiology \& Molecular Biology

Email: egyptianacademic@yahoo.com

ISSN: 2090-0767

Received: $2 / 10 / 2012$

www.eajbs.eg.net

\title{
Biological, biochemical and histological effects of spinosad, Bacillus thuringiensis var. kurstaki and cypermethrin on the Cotton leafworm, Spodoptera littoralis
}

(Boisd.).

\author{
El- Sheikh, T. A. A. \\ Plant Prot. Res. Inst., Agric. Res. Cent., Dokki, Giza, Egypt.
}

\begin{abstract}
The insecticidal, biological, biochemical and histological effects of bioagent spinosad, Diple 2x (Bacillus thuringiensis var kurstaki) and one pyrethroid compound (cypermethrin) were evaluated on $4^{\text {th }}$ instar larvae of Spodoptera littoralis (Boisd.) (Lepidoptera: Noctuidae). Based on the $\mathrm{LC}_{50}$ values Cypermethrin is the more toxic to $S$. littoralis than that of the two other compounds. Female longevity, fecundity and fertility were significantly reduced at all treatments compared to control. Furthermore, different levels of significant changes in the total protein, carbohydrate contents, phosphatasis activity and carbohydrasis, were recorded. Moreover, different abnormal histological structures of ovary were noticed.
\end{abstract}

Keywords: insecticidal, biological, biochemical and histological effects, spinosad, Diple 2x, pyrethroid compound.

\section{INTRODUCTION}

The cotton leafworm, Spodoptera littoralis is considered as one of the major and economic pests in Egypt, infesting over 112 plant species. The larval stage is known as a leaf eater accepting almost all herbaceous plants Abdel- Wahab (2002). The use of insecticides for control of such pest proved to be the most accepted during the recent years. However, the practical application of different insecticides extensively has resulted in several problems such as development of resistance in field population of insects (Frank et al., 1990). The current application of chemical insecticides on other crops is considered as one of the main factors affecting the agro ecosystem (plant, soil, water and other organisms). From this point of view, it is necessary to minimize the application of pesticides that considered as a main source of environmental pollution and use other compounds may proof as good alternative of insecticides. Among these compounds are the use of spinosad and Bacillus thuringiensis var. kurstaki in controlling this economic insect pest in comparing with synthetic pyrethroid cypermethrin.

\section{MATERIALS AND METHODS} Tested Compounds:

1- Bacillus thuringiensis var. kurstaki Berliner

Produced by Valent Biosciences Corporation - USA

Commercial name Dipel 2x

Common name Bacillus

thuringiensis var. kurstaki

2- Spinosad (Spintor ${ }^{\circledR}$, Tracery ${ }^{\circledR}, 24 \%$

S.C)

Source: Dow Agroscience Co.

3 - Cypermethrin

Commercial name Synthetic pyrethroid

Common name cypermethrin

Chemical formula $\mathrm{C} 22 \mathrm{H} 19 \mathrm{O} 3 \mathrm{NCl} 2$

Experimental techniques:

Rearing of the Egyptian cotton leafworm, Spodoptera littoralis.

Egg masses of the cotton leafworm, Spodoptera littoralis were obtained from Plant Protection Research Institute without any insecticidal pressure. Newly hatched larvae were transferred to clean glass jars covered with muslin held in position with rubber bands. They were 
fed on castor bean leaves, Ricinus communis, L. at $27 \pm 2{ }^{\circ} \mathrm{C}$ and $65 \pm 5 \%$ $\mathrm{RH}$ and examined daily (El-Defrawi et al., 1964). As larvae reached the $4^{\text {th }}$ instars, they were used in the experiments described below.

\section{Susceptibility tests}

A series of concentrations (in water) for each compound was prepared from the stock by diluting the commercial formulation. Castor-bean leaves were dipped for 30 seconds in each concentration then left to dry. The $4^{\text {th }}$ instar larvae were confined with treated leaves in glass jars covered with muslin for $24 \mathrm{hrs}$. Test also included a non treated control in which leaves were dipped in water (as a check). The average of mortality percentage was corrected using Abbott's formula (1925). The corrected mortality percentage of each compound was statistically computed according to Finney (1971). From which the corresponding concentration probit lines (LC-p lines) were estimated in addition to determine $50 \%$ and $90 \%$ mortalities, slope values of tested compounds were also estimated. The newly $4^{\text {th }}$ instars larvae feeded on leaves treated with calculated $\mathrm{LC}_{50}$ for each of these compounds and the survival larvae were transferred to other clean jars, and supplied with untreated leaves. Jars were inspected daily, then the newly cultures were treated with the $\mathrm{LC}_{50}$, the following some biological attributes such as adult longevity, fecundity and the percentage of egg-hatch or fertility also were determined. Sterility was calculated according to Toppozada et al. (1966) as follows:

$\%$ Sterility $=100-\frac{\mathrm{a} \mathrm{x} \mathrm{b}}{\mathrm{Ax} \mathrm{B}} \times 100$

where: $a=$ Number of eggs laid/female in treatment. $\mathrm{b}=\%$ of egg-hatch in treatment.

$\mathrm{A}=$ Number of eggs laid/female in control.

$\mathrm{B}=\%$ of egg-hatch in control.
Biochemical studies:

Preparation of samples for biochemical assay.

Haemolymph was collected from 3 pooled samples, each from 8-10 late $6^{\text {th }}$ instar larvae fed as $4^{\text {th }}$ instar for 24 hours on castor-oil leaves treated with the $\mathrm{LC}_{50}$ values of each tested compound. One of the prolegs was removed and the Haemolymph was collected in cold tubes (on ice) previously coated with crystals of phenylthiourea to prevent melanization. The samples were centrifuged at $2500 \mathrm{rpm}$ for 5 minutes under cooling $\left(4^{\circ} \mathrm{C}\right)$ to remove the blood cells. After centrifugation, the supernatant fluid was divided into small aliquots $(0.5 \mathrm{ml})$ and stored at $-20{ }^{\circ} \mathrm{C}$ until analysis.

\section{Determination of total soluble protein}

The protein content was determined using Folin phenol reagent according to the method of Lowry et al. (1951).

\section{Determination of total carbo-hydrate} content:

The total carbohydrate content of the haemolymph was determined according Singh and Sinha (1977).

Determination of phosphatasis activity Acid phosphatase activity:

Acid phosphatase activity was measured according to the method of Laufer and Schin (1971).

\section{Alkaline phosphatase activity:}

The same method of acid phosphatase activity was applied for the alkaline phosphatase activity but instead of acid buffer ( $\mathrm{pH} 4.8$ ), an alkaline buffer of $\mathrm{pH} 10.5$ was used .The activity was then measured specrophotometrically at $400 \mathrm{~nm}$.

\section{Carbohydrate hydrolyzing enzymes}

The methods used to determine the digestion of trehalose, starch and sucrose by trehalase, amylase and invertase enzymes respectively, were similar to those described by Ishaaya and Swiriski (1976).

\section{Histological studies:}

All tested compounds were applied to 
the $4^{\text {th }}$ instar larvae using the leaf dipping technique method at the recommended concentration of each tested compounds.

The Adult were taken after emergence then dissected, the ovary transferred into alcoholic Bouin's solution was used as a fixative, for dehydration and removal of the yellow colour of Bouin's solution the larvae were rinsed in a series of ethanol solutions. They were transferred first into $50 \%$ ethyl alcohol for $2 \mathrm{hrs}$ at $40 \mathrm{oC}$ (two changes) then left for 24 hours. Then the larvae passed through a series of alcoholic treatment each for two hours at room temperature starting with $80 \%$ followed by $90 \%, 96 \%$ and ending with $100 \%$ alcohol. After dehydration the larvae were placed in a solution of amyl acetate and colloiden in order to clear the tissues.

Treatment with soft wax started by placing the ovaries in vials containing equal portions for fresh amyl acetate solution and soft paraffin wax and leaving them for 24 hours at $50^{\circ} \mathrm{C}$. The ovaries were replaced by soft paraffin wax three times at $24 \mathrm{hrs}$ intervals at $50^{\circ} \mathrm{C}$. A mixture of one part of hard paraffin was added to the larvae. The ovaries were imbedded in wax mixture used in the last step. Serial longitudinal sections at 6 microns were made by microtome and mounted on clean slides using Mayer, s albumin. Sections were mounted on glass slides and stained with Haematoxylene and counterstained in alcoholic Eosin and prepared for observation and photomicroscopy.

\section{RESULTS AND DISCUSSION Susceptibility test:}

Table (1) reveals the $\mathrm{LC}_{50}$ values of the tested compounds against the newly molted $4^{\text {th }}$ instar larvae recording 28.86 , 7.59 and $1.675 \mathrm{ppm}$, for spinosad $B$. thuringiensis and cypermethrin, respectively. Based on the $\mathrm{LC}_{50}$ values Cypermethrin is the most toxic to $S$. littoralis than that of the two other compounds. The toxicity of spinosad and $B$. thuringiensis was significantly lower than that of the chemical insecticide cypermethrin that agree with El-Moursy et al. (2000) who stated that the latent toxicity of the bioinsecticide Delfin was significantly lower than that of the chemical insecticide pyrethroid. Similar findings was recorded by Abdallah (1982) on $S$. littoralis treated with $B$. thuringiensis who reported that the microbial pesticides Thuricide HP (B. thuringiensis subsp. kurstaki) and Bactospeine (B. thuringiensis subsp. thuringiensis) were equally effective against the $2^{\text {nd }}$ instar larvae of $S$. littoralis.

Table 1: Susceptibility of Spodoptera littoralis $4^{\text {th }}$ instar larvae to Spinosad, Bacillus thuringiensis and Cypermethrin

\begin{tabular}{|l|c|c|c|cc|c|}
\hline \multirow{2}{*}{ Treatments } & \multirow{2}{*}{\begin{tabular}{c}
$\mathrm{LC}_{50}$ \\
\cline { 3 - 4 }
\end{tabular}} & \multicolumn{2}{|c|}{$95 \%$ Fiducial limits } & \multirow{2}{*}{ Slope $\pm \mathrm{SE}$} & \multirow{2}{*}{$\mathrm{X}^{2}$} \\
\cline { 3 - 4 } & 28.86 & 24.72 & 33.59 & 3.59 & \pm 0.57 & 2.02 \\
\hline Spinosad & 7.59 & 6.33 & 9.29 & 2.58 & \pm 0.42 & 1.25 \\
\hline B. thuringiensis & 1.675 & 1.44 & 1.99 & 3.50 & \pm 0.60 & 6.88 \\
\hline Cypermethrin & &
\end{tabular}

On the other hand, the toxic effect of the used spinosad against $4^{\text {th }}$ instar larvae of Spodoptera littoralis in the present study is similar to the findings of Ayden and Gurkan (2006 ) using spinosad against S.littoralis larvae they suggest that spinosad is potentially important in the control of S. littoralis.

The slope value is known to be a very important feature of a regression line, since it helps to predict the reduction of a population. Comparatively average slope value (as those obtained in 
the present work) indicate heterogeneity in response to the tested compounds and hence the possibility of low decrease in sensitivity after continuous use of these compounds (El-Sebae et al. (1985).

Effects of $\mathrm{LC}_{50}$ of spinosad, $B$. thuringiensis, and cypermethrin on the life span of female moth:
Data in table (2) illustrated that the subdivisions of life span of female moths (pre-oviposition-, oviposition-, and postovipositional- periods) showed varied effects in response to different tested compounds. However, the female longevity was significantly reduced at all treatments as follow:-

Table 2: Effects of $\mathrm{LC}_{50}$ of Spinosad, Bacillus thuringiensis and Cypermethrin on life span of female moths of Spodoptera littoralis.

\begin{tabular}{|c|c|c|c|c|}
\hline \multirow{2}{*}{ Treatments } & \multicolumn{2}{|c|}{ Female life span in days (mean \pm SE) } & \multirow{2}{*}{$\begin{array}{c}\text { Total female } \\
\text { life span } \\
\text { in days } \\
\text { (mean } \pm \text { SE) }\end{array}$} \\
\cline { 2 - 4 } & $\begin{array}{c}\text { Pre Oviposition } \\
\text { period }\end{array}$ & $\begin{array}{c}\text { Oviposition } \\
\text { period }\end{array}$ & $\begin{array}{c}\text { Post Oviposition } \\
\text { period }\end{array}$ & $5.2 \pm 0.26^{*}$ \\
\hline Spinosad & $1.5 \pm 0.17$ & $2.5 \pm 0.1$ & $1.2 \pm 0.18$ & $6.7 \pm 0.31^{*}$ \\
\hline B. thuringiensis & $2 \pm 0.19$ & $3.2 \pm 0.16$ & $1.5 \pm 0.15$ & $6.5 \pm 0.23^{*}$ \\
\hline Cypermethrin & $3 \pm 0.17$ & $1.9 \pm 0.25$ & $1.6 \pm 0.11$ & $7.3 \pm 0.21$ \\
\hline Control & $2 \pm 0.14$ & $4.2 \pm 0.2$ & $1.1 \pm 0.13$ & \\
\hline
\end{tabular}

* significant at $\mathrm{P}=0.05$

Treatment with spinosad reduced the Pre-oviposition period than those of both B. thuringiensis and cypermethrin as compaired to control. On the other hand, oviposition and post oviposition periods were reduced in all treatment used as compaired to control .Over all female longevity was significantly reduced at all treatments which was recored $5.2 \pm 0.26$, $6.7 \pm 0.31$ and $6.5 \pm 0.23$ day for spinosad, B. thuringiensis and cypermethrin, respectively, compared with $7.3 \pm 0.21$ days of control. Adult longevity of moths was also significantly decreased in all treatments. It's cleared that from the sub divisions of life span of female moths (pre-oviposition-, oviposition, and post-ovipositionperiods) showed varied effects in response to different tested materials. However, the female longevity was significantly reduced that agree with
(Salama and Zaki (1986) who recorded that the percentage moth emergence, lifespan, egg production and fertility of the moths which emerged after treatment of prepupae decreased with an increase in concentration for both methods.

Effects of $\mathbf{L C}_{50}$ of spinosad, $B$. thuringiensis, and cypermethrin on fecundity, percentage of fertility and Sterility:

Data in table (3) revealed that the three tested compounds proved significant differences on females fecundity, fertility and sterility\%. Number of laid eggs/ female (fecundity) were significantly decreased at all treatments at which it reached to $388 \pm$ $15,592 \pm 13$, and $364 \pm 9$ for spinosad, $B$. thuringiensis and cypermethrin, respectively, with respect to control $682 \pm$ 19.

Table 3: Effects of $\mathrm{LC}_{50}$ of Spinosad, Bacillus thuringiensis and Cypermethrin on adult fecundity, fertility $\%$ and sterility $\%$ of Spodoptera littoralis.

\begin{tabular}{|l|c|c|c|}
\hline Treatments & Fecundity & \% Fertility $($ mean \pm SE) & \% Sterility \\
\hline Spinosad & $388 \pm 15$ & $74.88 \pm 4.2^{*}$ & $53.34 \pm 4.7$ \\
\hline B. thuringiensis & $592 \pm 13$ & $72.18 \pm 3.7$ & $31.37 \pm 1.2$ \\
\hline Cypermethrin & $364 \pm 9$ & $80.12 \pm 7.4^{*}$ & $53.16 \pm 3.9$ \\
\hline Control & $682 \pm 19$ & $91.93 \pm 5.3$ & 0.0 \\
\hline
\end{tabular}

* significant at $\mathrm{P}=0.05$ 
Fertility \% was decreased up to $72.18 \pm 3.7,74.88 \pm 4.2$ and $80.12 \pm 7.4$ for $B$. thuringiensis, spinosad and cypermethrin, respectively, as compared to $91.93 \pm 5.3$ in control. This is also true for the percentage of sterility at which the reduction was much obvious in case of B. thuringiensis treatment, followed by Cypermethrin and spinosad treatments.

The number of eggs laid per female moth of $S$. littoralis together with the percentage of egg-hatch were decreased due to treatment with all tested materials spinosad have a great effect on reduction of fecundity and fertility. Oviposition period was significantly decreased at $\mathrm{LC}_{50}$ of $B$. thuringiensis, spinosad and Cypermethrin respect to control. These results agree with those obtained by Gomaa (2005) using spinosad against the cotton $S$. littoralis. The apparently normal moths were small in size giving few numbers of small egg masses and even the tiny egg masses were sterile. The latent effect of the lowest concentration resulted in no development of the full-grown larvae to normal pupae or moths. From the present results that the tested materials proved significant differences at $\mathrm{LC}_{50}$ on females' fecundity and fertility.

\section{Biochemical studies}

Effects of $\mathbf{L C}_{50}$ of spinosad, $B$. thuringiensis and cypermethrin on total soluble protein and total carbohydrate contents of $6^{\text {th }}$ larval instar of S.littoralis:

Data in table (4) showed that treatment with both spinosad and cypermethrin significantly decreased total protein contents by about $31.5 \%$ and $48.4 \%$, respectively. Whereas, treatment with $B$. thuringiensis insignificantly increased total protein contents as compared to control. Protein content is very important in growth and development.

Table 4: Effects of $\mathrm{LC}_{50}$ of Spinosad, Bacillus thuringiensis and Cypermethrin on the mean total protein, carbohydrate contents (ug/ml) and mean phosphatasis activity (ug phenol $/ \mathrm{min} / \mathrm{ml}$ ) of $6^{\text {th }}$ larval instar of Spodoptera littorals treated as $4^{\text {th }}$ instar larvae.

\begin{tabular}{|c|c|c|c|c|c|c|c|c|}
\hline Treatments & $\begin{array}{c}\text { Mean total } \\
\text { protein (ug } \\
/ \mathrm{ml})\end{array}$ & Changes\% & $\begin{array}{c}\text { Mean total } \\
\text { carbohydrate } \\
\text { (ug / ml) }\end{array}$ & $\begin{array}{c}\text { Change } \\
\mathrm{s} \%\end{array}$ & $\begin{array}{c}\text { Mean Acid } \\
\text { phosphatas } \\
\text { e activity }\end{array}$ & $\begin{array}{c}\text { Changes } \\
\%\end{array}$ & $\begin{array}{c}\text { Mean } \\
\text { phosphatine } \\
\text { activity }\end{array}$ & $\begin{array}{c}\text { Change } \\
\text { s\% }\end{array}$ \\
\hline Spinosad & $\begin{array}{c}850 \\
\pm 22^{*}\end{array}$ & -31.5 & $259 \pm 8^{*}$ & -26.7 & $4.12 \pm 0.3$ & 42.1 & $6.55 \pm 0.4$ & $39.1^{*}$ \\
\hline Bt. & $\begin{array}{c}1260 \\
\pm 37\end{array}$ & 1.6 & $308 \pm 11^{*}$ & -12.8 & $4.30 \pm 0.1$ & 48.3 & $6.13 \pm 0.5$ & $30.1^{*}$ \\
\hline $\begin{array}{c}\text { Cypermeth } \\
\text { rin }\end{array}$ & $\begin{array}{c}640 \\
\pm 19^{*}\end{array}$ & -48.4 & $197 \pm 6^{*}$ & -44.2 & $4.43 \pm 0.2$ & 52.8 & $6.76 \pm 0.4$ & $43.5^{*}$ \\
\hline Control & $\begin{array}{c}1240 \\
\pm 24\end{array}$ & - & 353 & - & $2.9 \pm 0.1$ & - & $4.71 \pm 0.2$ & - \\
\hline
\end{tabular}

*significant at $\mathrm{P}=0.05$

In the present work total protein content in the $6^{\text {th }}$ instar larvae of $S$. littoralis larvae, significantly decreased after treatment with cypermethrin and spinosad. This agree with Shaaban et al. (1985) which reported that total haemolymph protein content of 6th instar larvae of $S$. littoralis decreased after treatment of the $4^{\text {th }}$ larval instar with pyrethroid compounds. The decrease in the protein content of the haemolymph in the present work might be due to inhibition of DNA and RNA synthesis, as suggested by Mitlin et al. (1977) for boll weevils treated with chitin synthesis inhibitors and by Qadri and Narsaih (1978) for last nymphal instar of P. americana injected with azadirachtin.

On the other hand, all treatments significantly decreased total carbohydrate 
contents by about $26.7 \%, 12.8 \%$ and $44.2 \%$ for spinosad, B. thuringiensis and cypermethrin, respectively, as compared to control. The total carbohydrates content in $6^{\text {th }}$ larval instar treated with spinosad, B. thuringiensis and cypermethrin significantly decreased, parallel results were recorded for the carbohydrate content of the $6^{\text {th }}$ instar larvae of $S$. littoralis treated with $B$. thuringiensis (El-Leithy et al, 2004).

Effects of $\mathbf{L C}_{50}$ spinosad, $B$. thuringiensis and cypermethrin on Phosphatasis activity

Data in table (4) showed that the acid phosphatase activity was significantly increased by about $42.1 \%$, $48.3 \%$ and $52.8 \%$ after treatment with spinosad, B. thuringiensis and cypermethrin, respectively, as compared to control. On the other hand, a significant increase in the activity of alkaline phosphatase by about $39.1 \%$, $30.1 \%$ and $43.5 \%$ after treatments with spinosad, B. thuringiensis and cypermethrin, respectively, in respect to control.

A significant increase in phosphatasis activity was similar to the results obtained by (El-Sheikh et al., 2009). Who reported that the activity of haemolymph acid and alkaline phosphatase activity was significantly increased after treatment of $S$. littoralis with spinosad and tebufenozide. Acid and alkaline phosphatase have been shown to be associated with insect development especially in relation to nutrition and egg maturation (Tsumuki and Kanehisa 1984). A significant increase in acid phosphatase activity after treatment with $B$. thuringiensis and spinosad may attribute to its role in the competition of infection as it is synthesized from haemocytes and has an immune role (El-Sheikh et al, 2009).

Effects of $\mathbf{L C}_{50}$ of spinosad, $B$. thuringiensis and cypermethrin on carbohydrates hydrolyzing enzymes of $6^{\text {th }} \quad$ instar larvae of Spodoptera littoralis:

\section{Amylase enzyme:}

Data in table (5) showed that the amylase activity through the present study was significantly increase in case of spinosad treatment by about $45.4 \%$, on the other hand, treatment with cypermethrin significantly decreased its activity to $12.9 \%$, whereas treatment with $B$. thuringiensis insignificantly decrease such activity as compared to the untreated one. This is parallel to El-Ghar et al. (1995) which found that B. thuringiensis caused a remarkable decrease in amylase activity at which maximum inhibition, about $77 \%$ was recorded 3 days after treatment.

Table 5: Effects of $\mathrm{LC}_{50}$ of Spinosad, Bacillus thuringiensis and cypermethrin on the mean carbohydrates hydrolyzingenzymes (ug glucose $/ \mathrm{min} / \mathrm{ml}$ ) of $6^{\text {th }}$ instar larvae of S.littoralis treated as $4^{\text {th }}$ larval instar.

\begin{tabular}{|c|c|c|c|c|c|c|}
\hline Treatment & $\begin{array}{c}\text { Amylase } \\
\text { enzyme }\end{array}$ & Changes\% & $\begin{array}{c}\text { Invertase } \\
\text { enzyme }\end{array}$ & Changes\% & $\begin{array}{c}\text { Trehalase } \\
\text { enzyme }\end{array}$ & Changes\% \\
\hline Spinosad & $192 \pm 4$ & $45.4^{*}$ & $322 \pm 8$ & $27.7^{*}$ & $252 \pm 5$ & $-10.4^{*}$ \\
\hline B. thuringiensis & $124 \pm 6$ & -6.1 & $323 \pm 12$ & $27.5^{*}$ & $268 \pm 8$ & -4.7 \\
\hline Cypermethrin & $115 \pm 5$ & $-12.9^{*}$ & $299 \pm 4$ & $32.9^{*}$ & $265 \pm 6$ & -5.7 \\
\hline Control & $132 \pm 2$ & - & $445 \pm 7$ & - & $281 \pm 3$ & - \\
\hline
\end{tabular}

* significant at $\mathrm{P}=0.05$

\section{Invertase enzyme.}

Data in table (5) showed that the tested compound have a remarked effect on invertase activity spinosad, Bacillus thuringiensis and cypermethrin were significantly decreased the invertase activity compared to the untreated larvae as follow $(27.7 \%, 27.5 \%$ and $32.9 \%$, respectively, compared to untreated one. 
In the present study spinosad decrease the activity of invertase these results agree with those obtained by ElMageed et al. (2006) observed that Spinosad decreased invertase activity in $4^{\text {th }}$ instar larvae of S. littoralis. moreover, similar results was obtained by El-Ghar et al. (1995) who found that $B$. thuringiensis, caused a pronounced decrease in digestive enzyme activity especially invertase.

Trehalase enzyme.

Data in table (5) showed that the the changes $\%$ in trehalase activity significantly decreased after treatment with spinosad up to $10.4 \%$, whereas, insignificant decrease in enzyme activity was recorded after treatment with $B$. thuringiensis and cypermethrin.

Trehalase is activated for the production of glucose needed for chitin build-up in the newly synthesized cuticle; it is generally present in large amounts in the haemolymph of most insects and it has the important function of energy supply to insect; and its activity might be an indicator of energy reserves resulting from availability of carbohydrate nutrient (Wyatt, 1967). They added that, haemolymph trehalose is an important source of energy and chitin biosynthesis. Steel and Hall (1985). The decrease in trehalase activity was similar with ElGhar et al. (1995) who stated that B. thuringiensis at concentration of 200 ppm. reduced trehalase activity by $53 \%$ after 2 days of treatment.

\section{Histological studies}

Effects of $\mathrm{LC}_{50}$ of spinosad, $B$. thuringiensis and cypermethrin on reproductive system of female moth of Spodoptera littoralis:

\section{Ovaries of normal female}

The reproductive system of cotton leafworm, S. littoralis formed of two ovaries each normal ovary formed of four ovarioles each of which is enclosed in a syncitical outer epithelial sheath. The ovariole consists of the terminal filament, germarium, vitellarium and the pedicle.
Each ovariole contains a chain of developing ova which have defined spherical shape Figure (1). The oocyte enclosed with in follicle. The oocytes are well differentiated and have branched nuclei contained dispersed chromatin granules. The follicular cells are columnar in shape and cover the oocyte. The follicular epithelium changes to cuboidal in shape with later growth of the oocyte. Figure (2) show accumulation of the yolk in the egg, while, the oocyte is declining and their cytoplasm is reduced to a thin film surrounding the depressed nuclei. The follicular cells surrounding the oocyte push a septum of squamous follicular cells which cuts off the oocyte from its degenerating nurse cells.

\section{Ovaries of treated female}

In the present study, ovaries of female moths resulted from treated $4^{\text {th }}$ instar larvae with the three tested compounds were dissected and examined. Their ovarioles had some abnormal oocytes. They showed a variable number of eggs in their ovarioles occupying different parts. In case of ovarioles resulted from larvae treated with $B$. thuringiensis there is change only in the shape and size of the oocyte and some ovarioles are malformed, others in a state of deterioration being resorbed Figure (3). The size of the ovarioles of the female moths resulted from larvae treated with spinosad and cypermethrin show a great significant decrease in size compared with the size of untreated one. The degenerating eggs lost their spherical shape without separating boundaries between adjacent eggs and some of them changed their color to yellow as a result of destruction of egg in the ovarioles as shown in Figures (4) and (5). Ovary resulted from larvae treated with $B$. thuringiensis show no significant difference from the control except some small vacuoles Figure (3). While, in case the histological effects of female moths ovary resulted from larvae treated with cypermethrin oocytes and nurse cells of 
the treated females were significantly vacuolated due to the degeneration of the oocyte Figure (5) the follicular epithelium lost its normal cytological organization.

Ovary resulted from larvae treated with spinosad the follicular epithelium lost its normal cytological organization. The central mass of yolk within the egg was reduced and vacuolated indicating shrinkage of the yolk Figure (4). The whole normal appearance was changed, where components shifted their ordinary positions and arrangement in the ovarioles. Oocytes lost their regular and characteristic shape. It could be concluded from the present data that Cypermethrin and Spinosad cause detachment of the follicular epithelium in the oocytes of the treated females of S. littoralis. The histological changes due to the effect of various compounds had been a subject of considerable discussion among various authors as they are the primary cause of insect's inactivity, decrease fecundity, hatchability and consequent death. Many of the histological changes of the ovary observed in the present study for S.littoralis larvae due to treatment with the B.thuringiensis, Spinosad and Cypermethrin are parallel to Perlak et al., (1993) which found a reduction in the size of ovarioles of Colorado potato beetles, Leptinotarsa decemlineata, fed on transgenic potato carrying the gene coding for CryIII endotoxin protein of $B$. thuringiensis. On the other hand, in case of female moth resulted from larvae treated with B.thuringiensis, it was of normal size, ovarioles this data agree with EL Sawaf (1971) who found no effect of sub lethal treatment of some chemical insecticides on the structure of the reproductive system of $S$. littoralis. The histological effects of cypermethrin and spinosad on the ovaries indicate that both oocytes and nurse cells of the treated females were significantly vacuolated due to the degeneration of the oocyte, the follicular epithelium lost its normal cytological organization. The follicular epithelium lost its normal cytological organization. The central mass of yolk within the egg was reduced and vacuolated indicating shrinkage of the yolk. The whole normal appearance was changed, where components shifted their ordinary positions and arrangement in the ovarioles. Oocytes lost their regular and characteristic shape. Areas in the ovarioles containing degenerating eggs colored ring shapes between normal oocytes. Similar results were obtained by EL Sawaf (1971) on the same insect treated with chemical insecticides. This data agree also with Shurab et al, (1999) reported completely damage for A.ipsilon female ovariolar cells when treated as fourth instars with chlorofluazuron. The presence of vacuoles within oocytes and shrinkage or degeneration of yolk in the gonad tissues may be attributed to an increase in the osmotic pressure of the plasma membrane of oocytes which may lead to water loss or dehydration that causes the occurrence of dominant vacuoles (Shurab et al, 1999; Abdel- Aal and Abdel-Wahab, 2007). El Sawaf (1971) has attributed the histological effect to a direct interference of toxins with the hormonal system of the insect. It could be concluded from the present data that Cypermethrin and Spinosad cause detachment of the follicular epithelium in the oocytes of the treated females of S. littoralis, ( pr-treatment as larvae) Similar observations were recorded in houseflies treated with hempa insecticide (Philip, 1967); Locusta migratoria treated with azadirachtin natural botanical extract, irradiated cut worm (Lutfallah et al., 1985).

\section{REFERENCE}

Abbott, W. S. (1925). A method of computing the effectiveness of an insecticide. J. Econ. Entomol. 18: 265 $-267$. 
Abdallah, S. A. (1982). Efficacy of certain synthetic pyrethroids, $B$. thuringiensis and their combination on the Egyptian cotton leaf worm, Spodoptera littoralis (Boised.). Bull. Entomol. Soc. Egypt. (13):145-155.

Abdel - Aal , Aziza. E and Abdel Wahab, I.S. (2007). Ovicidal and latent effects of lufenuron and spinosad on the cotton leafworm, Spodoptera littoralis (Boisd.) J. Agric.Sci. Mansoura Univ., 32 (6): 4806, 2007.

Abdel-Wahab, I. S. (2002). Factors stimulating the outbreaks of the cotton leafworm, in Assuit Governrate. $2^{\text {nd }}$ international conference, Plant Protection Research Iinstitute, Cairo, Egypt, 21 - 24 December, 2002.

Aydn,-H; Gurkan,-M-O (2006). The efficacy of spinosad on different strains of Spodoptera littoralis (Boisduval) (Lepidoptera: Noctuidae. Turkish-Journal-of-

Biology.30(1):NO.5-9.

El-Defrawi, M. E.; Toppozada, A.; Mansour, N. and Zeid, M. (1964). Toxicological studies on the Egyptian cotton leafworm, Prodenia littura (L.). I.Susceptibility of different larval instars of Prodenia to insecticides. J. Econ. Entomol., 57:591-593.

El-Ghar, G.E.S.A.; Radwan, H.S.A.; ElBermawy, Z.A. and Zidan, L.T.M. (1995). Inhibitory effect of $B$. thuringiensis and abamectin on digestive enzymes and non-specific esterases of Spodoptera littoralis (Boisd.) (Lepidoptera: Noctuidae) larvae. J. App. Entomol., 119(5): 355359.

El-Leithy, M. A.; Saleh,W.D.; Fathy, H.M. (2004). Isolation and insecticidal activity of Bacillus thuringiensis strains obtained from North Sinai, Egypt. Egyptian Society for Biological Control of Pests. 14(2): 379-386.

El-Mageed, A.E.M.A.; Elgohary, L.R.A. (2006). Impact of spinosad on some enzymatic activities of the cotton leafworm. Pakistan-Journal-ofBiological-Sciences. 9(4): 713-716.

El-Moursy, A.A.; Kares, E.A.; Zohdy, N.; Abdel - Rahman, A.M. and El Mandarawy, M.B.R. (2000). Effect of Bacillus thuringiensis Berliner, a chemical insecticide and its mixtures against unparasitized and parasitized Spodoptera littoralis (Boisd.) Larvae. Egypt. J. Agric. Res., 78 (4): 15871601.

El-Sawaf, B. M. (1971). Effect of some chemical insecticides on the reproductive system and reproduction in the cotton leafworm, (Spodoptera littoralis) Boisd. (Prodenia litura). $\mathrm{Ph}$. D. degree, Ain Shams University, faculty of science.

El-Sebae, A.H; Enan, E.E; Daoud, A.S; Zeid, M.I. (1985). Selective toxicity of synthetic pyrethroids and some synergists to mice and cotton leafworm in relation to some biochemical enzymes activities. Mededelingen-van-de-Faculteitlandbouww-etenschappen, Rijksuniversiteit-Gent.50(3a): 939950.

El- Sheikh. .T.A; Aziza .E .Abdel-aal and Farag, A.M. (2009). Effect of Spinosad and Tebufenozide on some biological, biochemical and immunological parameters of cotton leafworm, Spodoptera littoralis (Boisd.) Egypt. J. Agric. Res., 87 (2): 73-90

Finney, D.J. (1971). Probit analysis. A Statistical Treatment of the Sigmoid Response Curve. 7th Ed., Cambridge Univ. Press, England.

Frank, R.; Braun, H. E.; Ripley, B. D. and Clegy, B. S. (1990). Contamination of rural ponds with pesticides, 1971-1985. Ontario, Canada. Bull. Environm. Contam. Toxicol., 13: 771-817.

Gomaa,A.E. (2005). The biochemical effect of spinosad for the control of the cotton leafworm Spodoptera 
littoralis (Boisd.). Egyptian J. Agric. Res., 83(1): 33-46.

Ishaaya, I. and Swiriski, E. (1976). Trehalase, invertase and amylase activities in the black scale, Saissetia oleae and their relation to host adablebility. J. Ins. Physiol., 16 : 1025-1025.

Laufer, H. and Schin, K. S. (1971). Quantitative studies of hydrolytic enzymes activity in the salivary gland of Chironomus tentans (Diptera: Chironomidae)during metamorphosis.Can. Entomol., 103: 454-457.

Lowry, O. H.; Rosebrough, N. J.; Farr, A. L. and Randall, R. J. (1951). Protein measurement with folin phenol reagent. J. Biol. Chem., 193: 265-275.

Lutfallah, A. F.; Abd El-Meneam, E. M. and Bishara, S. J. (1985). Histopathological effect of irradiation on the ovary of the cutworm Agrotis ipsilon (Hufn.). Bull. Ent. Soc. Egypt, Econ. Ser. ,14:(343).

Mitlin, N.; Wiygul, G. and Haynes, J. W. (1977). Inhibition of DNA synthesis in boll weevil (Anthonomus grandis Boheman) sterilized by Dimilin. Pestic. Biochem. Physiol., 7: 559-563.

Perlak, F. J.; Stone, T. B.; Muskopf, Y. M.; Petersen, L. J.; Paker, G. B.; McPherson, S. A.; Wyman, J.; Love, S.; Reed, G.; Biever, D. and Fischhoff, D. A. (1993). Genetically improved potatoes: protection from damage by Colorado potato beetles. Plant Mol. 22:313-321.

Philip, B. M. (1967). Effect of Hempa on the ovarian development of the house flu Musca domestica (Diptera: Muscidae). Ann. Entomol. Soc. Amer. 60:812-818.

Qadri, S. S. H. and Narsaih, S. (1978). Effect of azadirachtin on the moulting process of last instar nymph of Periplaneta americana (L.). Ind. J. Exp. Biol., 16: 1141-1143.
Salama, H.S. and Zaki, F.N. (1986). Effect of Bacillus thuringiensis Berliner on prepupal and pupal stages of Spodoptera littoralis (Boisd.) (Lepidoptera: Noctuidae). Insect Sci. and Appl., 7(6): 747-749.

Shaaban, A. M; Abo-Elghar, M. R; Abdel-Mohymen, M R; El-Malla, M (1985). AResistance of the Egyptian cotton leafworm, Spodoptera littoralis (Boisd.), to certain insecticides. Zeitschrift-fur-Pflanzenkrankheitenund-Pflanzenschutz. 92 (1): 69-75.

Shaurub, E. H.; Emara, S. A.; Zohdy, N. Z. and Abdel-Aal, A. E. (1999). Effect of four insect growth regulators on the black cutworm, Agrotis ipsilon (Hufn.) (Lepidoptera: Noctuidae). The $2^{\text {nd }}$ Int. Conf. of Pest Control, Mansoura, Egypt, Sept., PP: 773-776.

Singh, N. B. and Sinha, R. N. (1977). Carbohydrates, lipids and proteins in the developmental stages of Sitophilus oryzae and S. granarius (Coleoptera: Curculionidae).Ann. Entomol. Soc. Amer., 70: 107-111.

Steel, J. E. and Hall, S. (1985): Trehalose synthesis and glycogenolysis as site of action for the corpora cardiacum in Periplaneta americana . Insect Biochem., 15: 529536.

Toppozada, A.; Abdallah, S. and ElDefrawi, M. E. (1966). Chemosterilization of larvae and adults of the Egyptian cotton leafworm, Prodenia litura by apholate, metepa and tepa. J. Econ. Entomol., 59: 1125-1128.

Tsumuki, H. and Kanehisa, K. (1984). Phosphatases in the rice stem borer, Chilo supperssalis Walker (Lepidoptera, Pyralidae): Some properties and changes of the activities during hibernation. Cryobiology, 21: 177-182.

Wyatt, G. R. (1967). In Insect Biochemistry and function (Candy and Kilby) 89-154, Chapman and Hall, London. 


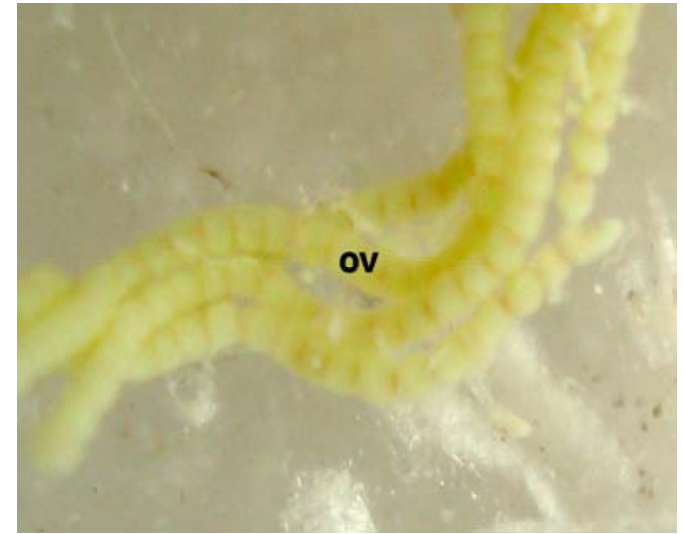

Fig. 1: Normal ovarioles of healthy female moth of S.littoralis Showing the shape of ovarioles.

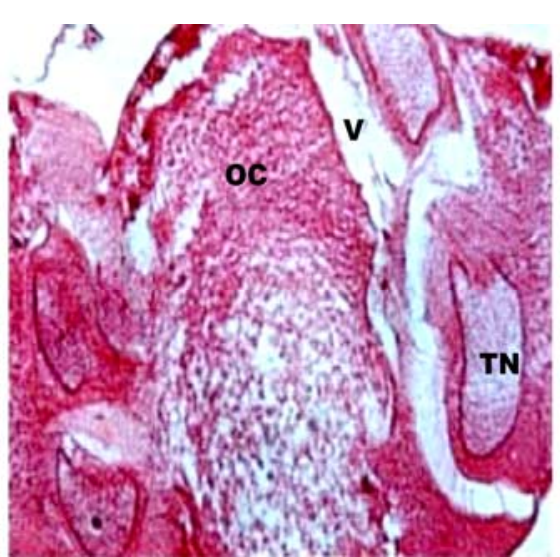

Fig. 3: Longitudinal section of ovarioles of female moths resulted from $4^{\text {th }}$ instar treated larvae of S.littoralis with Bacillus thuringiensis showing the permanent Vacuoles.

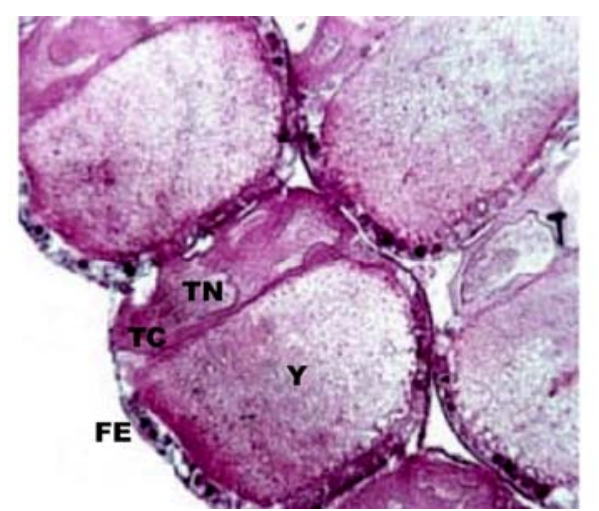

Fig. 2: Longitudinal section of healthy ovarioles of Spodoptera littoralis female moths.

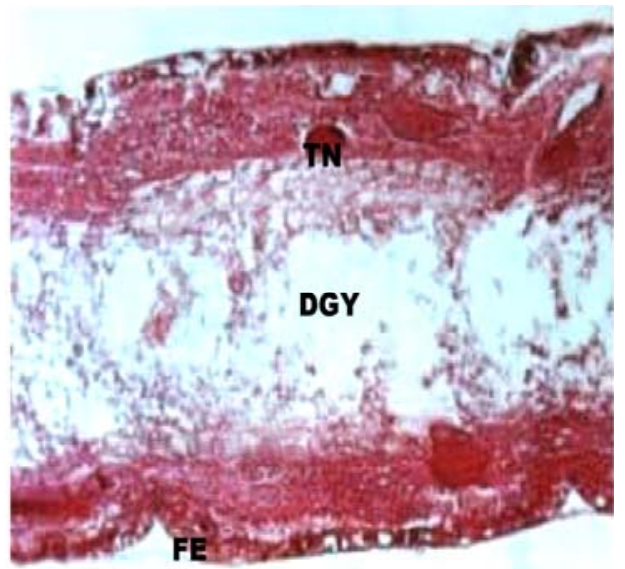

Fig. 4: Longitudinal section of ovarioles of female moths resulted from $4^{\text {th }}$ instar treated larvae of S. littoralis with Spinosad Showing degenerated yolk.

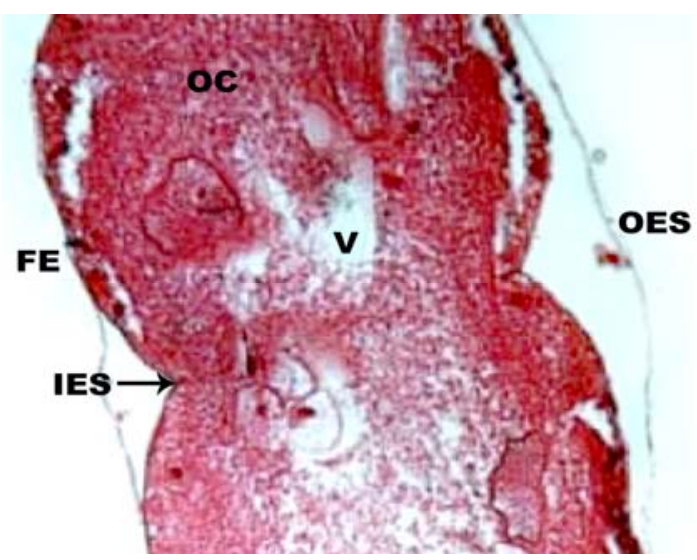

Fig. 5: Longitudinal section of ovarioles of female moths resulted from $4^{\text {th }}$ instar treated larvae of S.littoralis with Cypermethrin Showing the permanent Vacuoles.

TN Trophocyte nucleus OC. Oocyte

FE Follicular epithelium TC. Trophocyte cytoplasm

Y normal yolk. OV Ovarioles

IES inner epithelial sheath OES Outer epithelial sheath DGY degenerated yolk. 


\section{ARABIC SUMMARY}

التأثيرات البيولوجية و البيوكيميا ئية و الهيستولوجية للسبينوساد والباسيلس ثيورينجنسس والثيبرميثرين

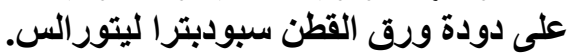

$$
\text { معهد بحوث وقاية النباتات - مركز البحوث الزراعية }
$$

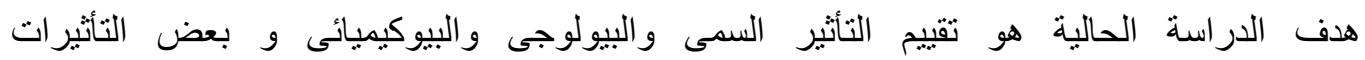

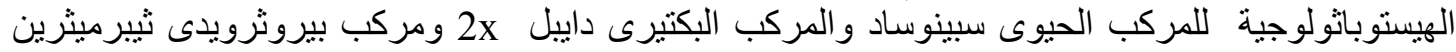

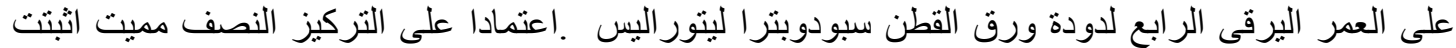

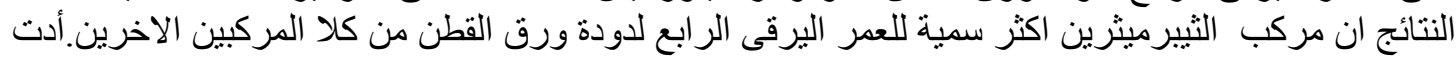

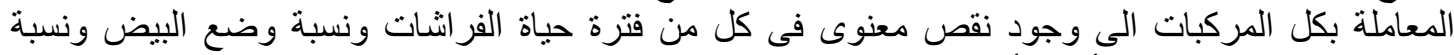

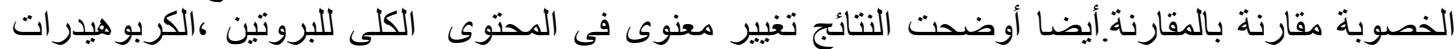

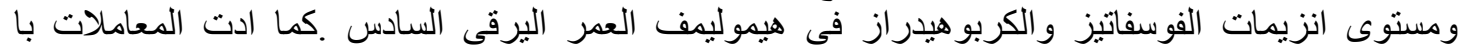

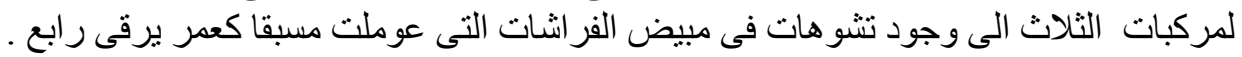

